\title{
Role of the Media in Turkey-Russia Relations
}

\author{
Dr. Gönül Cengiz \\ Assistant Professor of Kahramanmaras Sutcu Imam University, \\ Department of Cinema and Television, Kahramanmaras, Turkey
}

\begin{abstract}
Cultural and inter-civilization interaction between Russia and Turkey, today both governments have deep historical prestige and strong cultural roots that can bring the geopolitical role in the international arena closer in the sense of the Eurasian approach. One of the most important tools in the realization of this interaction is mass media. The media is one of the most active, powerful and confident forces that make public awareness, not only public but also manipulating political processes.

Russia and Turkey media reflects in all aspects of relations between the two countries actively and consistently. The media of both states deal with many issues related to both domestic and foreign politics, usually based on the national economic interests, based on the problems of intergovernmental relations that are mutually beneficial in the economic sphere. New geopolitical conditions have changed the restructuring and priorities of media work of both countries.

The role of journalism in the bilateral relations of the Russian and Turkish media and the handling of the current issues of Russian-Turkish relations also determine the image of both states in the Western media. The objective of the research constitutes the interstate political relations system and the media to examine the role of Russia and Turkey as well as relationships with one another, at the same time, to investigate whether the principles of journalism are being observed. The news sites of these countries are analyzed through content analysis method in 2018. At the same time, news coverage includes bilateral relations.
\end{abstract}

As a result of research Turkey stance against Russia in the media, more objective, careful, realistic and well-intentioned rule is seen as versatile. Turkish journalists are in the process of participation in joint projects with Russian media that attitudes toward Russia in the formation of Turkey's media image is affected in a positive

Analyzing what interests Russia pursues, rendering support for Syria, the Turkish media agreed that the primary danger for Moscow is not way. In the Russian media it has reached the conclusion that given the news about Turkey as negative interpretive, more biased and unidirectional.

Keywords: Turkey, Russia, Media

\section{INTRODUCTION}

During the past 250 years, Russia has been characterized as Turkey's largest and most important neighbor and as the most serious competitor in the inner circle. Turkish political, military, economic and strategic relations, strengthened since 1992, began to cool in 2008 due to disagreements on a number of issues (Caucasus, Middle East). The development of relationships is reflected through the media (Öztürk, 2017: 146). The information space of Russia and Turkey covers all areas of active cooperation between the two countries.

\section{INTERNET NEWS (2018) IN TURKEY- RUSSIA RELATIONS}

A comparison of the interest of Russian and Turkish news sites to various topics demonstrates that global issues of domestic and foreign policy are undoubted favorites. The most discussed topic in the media of both countries in the context of relations with Turkey and Russia can be listed as follows.

a. Russia's participation in the Syrian conflict

b. The attention of the Turkish mass media to the topic "Energy" is connected with the active coverage of the gas policy of Russia.

c. Terrorism

d. Tourism

\section{a. RUSSIA'S PARTICIPATION IN THE SYRIAN CONFLICT}

Turkish Media Approach

a change of regime, but a change in the overall distribution of forces in the region (MIRNaS, 2015: $15)$. 


\section{in Social Sciences}

\section{İdlib'de silahlardan arındırılmış bölgeden çıkış sinyalleri}
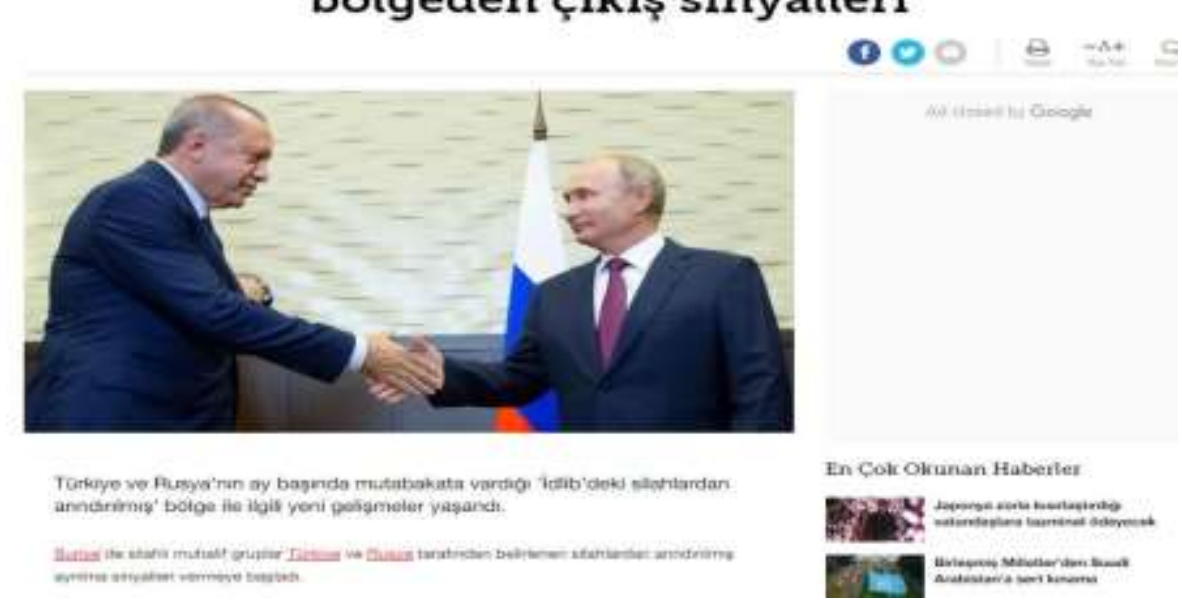

http://www.hurriyet.com.tr/dunya/idlibde-silahlardan-arindirilmis-bolgeden-cikis-sinyalleri-40969246

Russian Media Approach

Turkey's approach to Syria shows itself more firmly in the Russian media. Especially Russian press had carried the President of Turkey Recep
Tayyip Erdogan's rhetoric to news headlines and in this case, the West, seeks to incite against Turkey.

\section{๑w \\ ТЕМЫДНЯ MЕДИАТЕКА УЧИТБ HEMEUКИЙ DW AKADEME

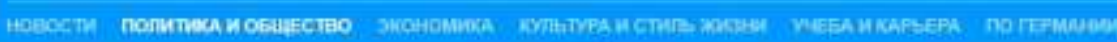

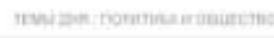 \\ MSTP \\ Какую цель преследует Турция в Сирии?

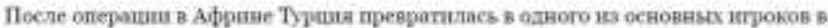

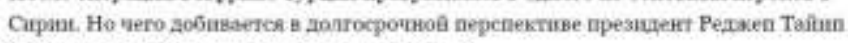

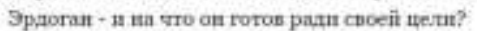

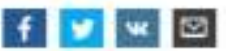

www.dw.com/ru/какую-цель-преследует-турция-в-сирии/a-43080992

\section{b. ENERGY}

One of the leading topics in the Turkish information space has become the export of Russian gas. First of all, the media discussed its cost, as well as the possibility of reducing the purchase price for the Turkish side. The issue of discounts on gas supplied from Russia to Turkey has become a key issue in a number of media. 


\section{in Social Sciences}

Turkish Media Approach

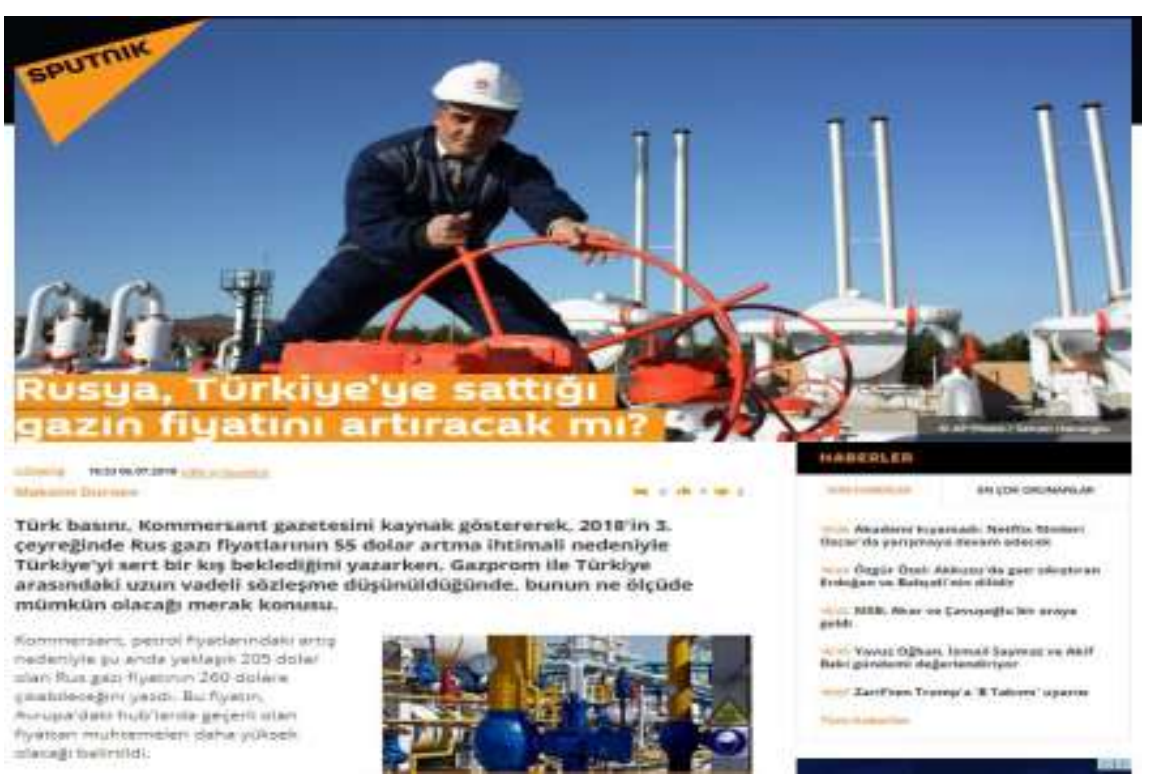

https://tr.sputniknews.com/columnists/201807061034177253-rusya-turkiye-sattigi-gazin-fiyatini-artiracak-mi/

Russian Media Approach

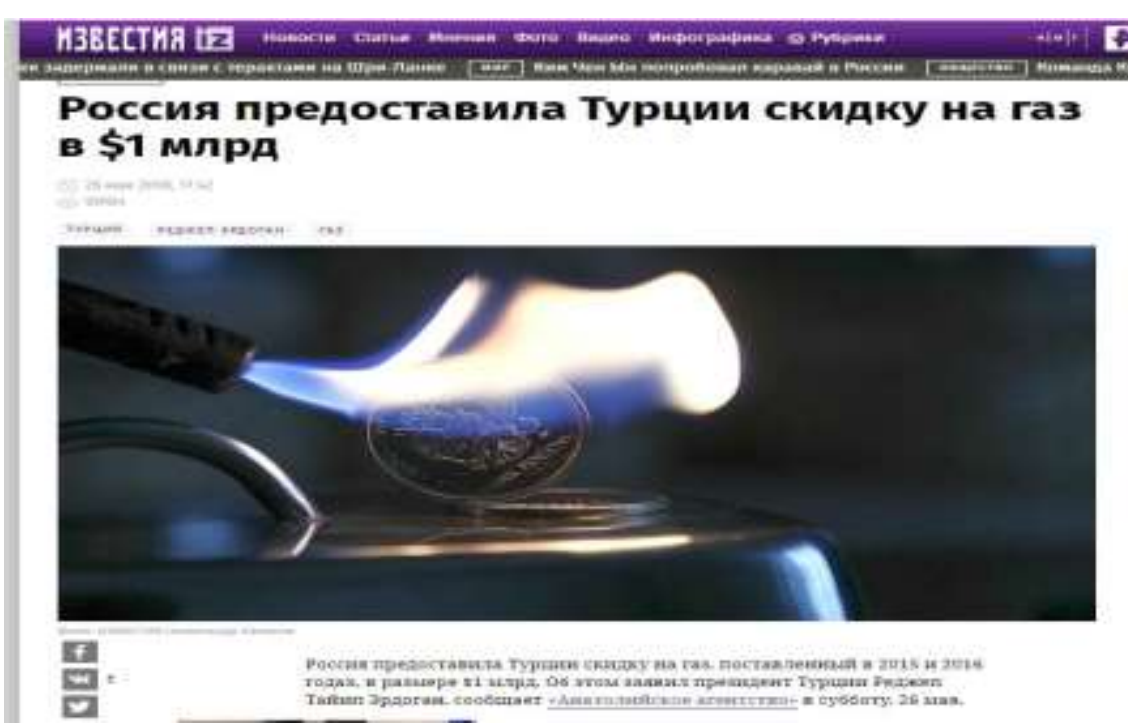

https://iz.ru/748313/2018-05-26/rossiia-predostavila-turtcii-skidku-na-gaz-na-1-mlrd

\section{c. TERRORISM}

The problem of terrorism in Russia was also widely reported in the Turkish media. A 17 year old person's Russian intelligence in the city of Arkhangelsk in northern Russia's Federal Security Service (FSB) stating carried out bomb terrorist attack on the building entrance NTV news site in Turkey has also nderlined that condemned this terrorist incident. 


\section{in Social Sciences}

Turkish Media Approach

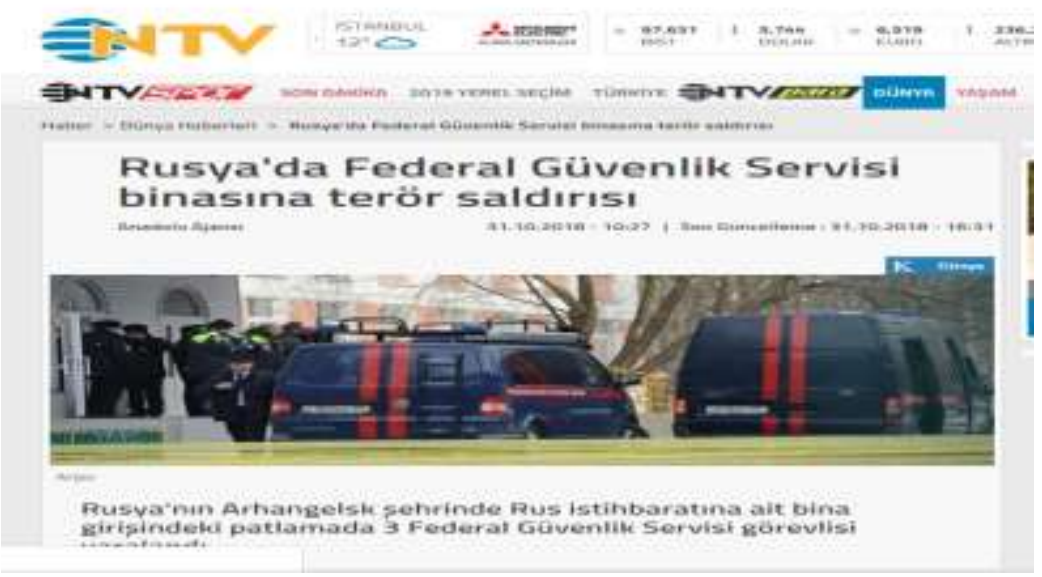

www.ntv.com.tr/dunya/rusyada-federal-guvenlik-servisi-binasina-teror-saldirisi,tqQ_orNoDUygp7S9E9bLSQ

Russian Media Approach

Russian media is opposed to the terrorist attacks in Turkey. Russian media have shown a strong attitude towards terrorism especially the martyrs who lost their lives in the terrorist attacks by the PKK. In case of terrorist operations in Syria occurred in 2018 in Afrin unflattering Russian media is the same approach with Turkey on terrorism.

\section{Террор по-курдски: взрывы и кровь под небом Турции}

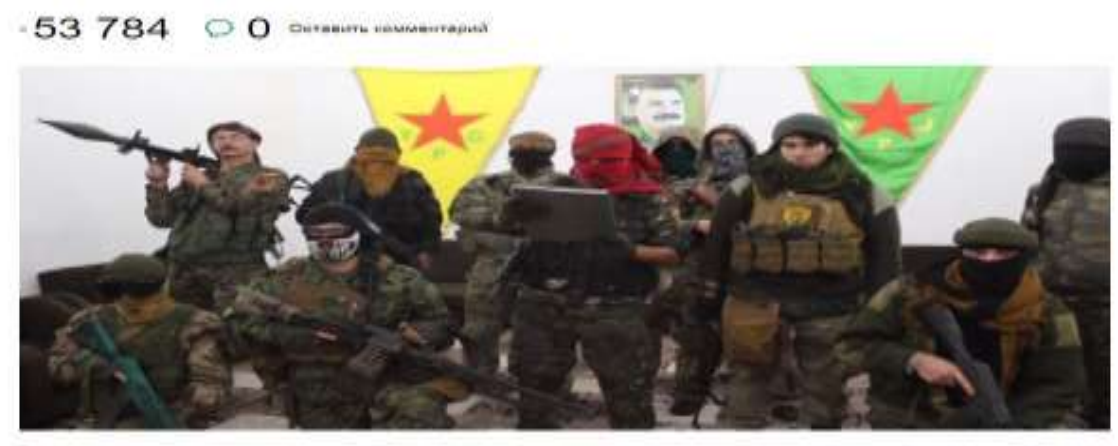

страсти, разгореөшиося в Великобритании вокруг инцидента о отравлением в Солобери, а также перипетии преаидентеких иыборов в России 18 марта подняли такои информационньіи шум, что за этой "дьімоиои завесои" осталсн почти незамеченнцім вход турецкой армии в сириискии город Африн - столицу рвсположенного в 60 км K sarraдy or Anenno курдского анклава.

https://riafan.ru/1037974-terror-po-kurdski-vzryvy-i-krov-pod-nebom-turcii

\section{d. TOURISM}

The majority of Russians come to Turkey every summer for vacation. News about tourism are news that are frequently given every summer on both countries' news sites. 


\section{in Social Sciences}

Turkish Media Approach

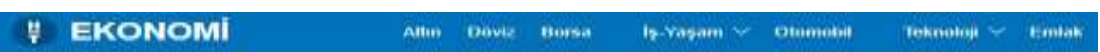

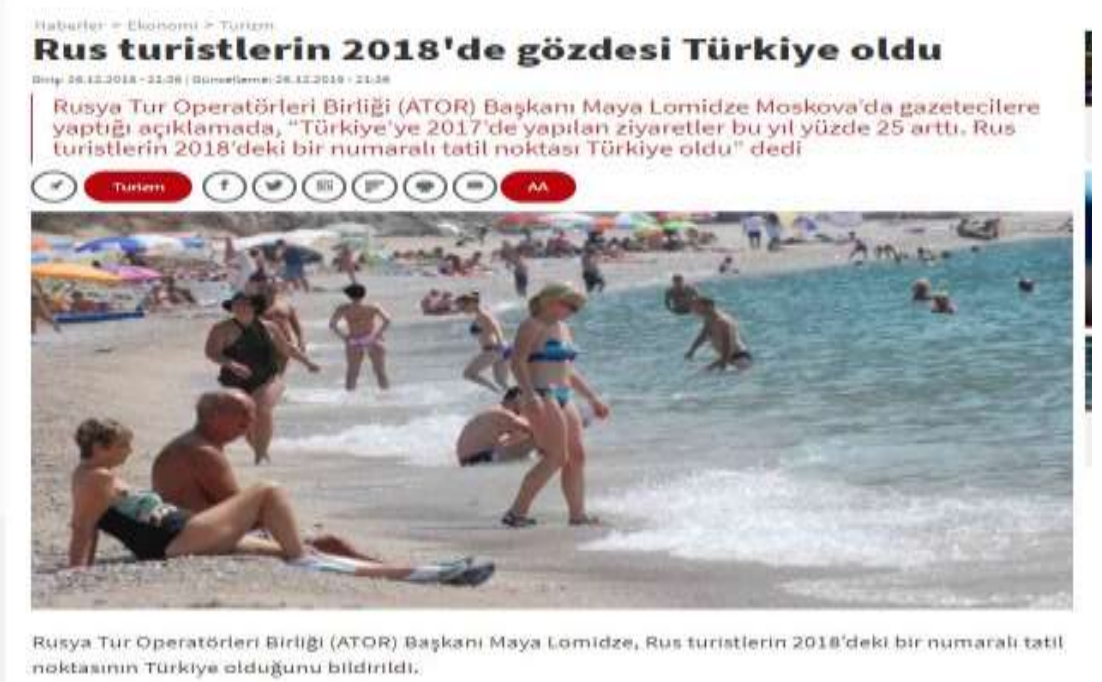

www.haberturk.com/rus-turistlerin-2018-de-gozdesi-turkiye-oldu-2273581-ekonomi

Russian Media Approach

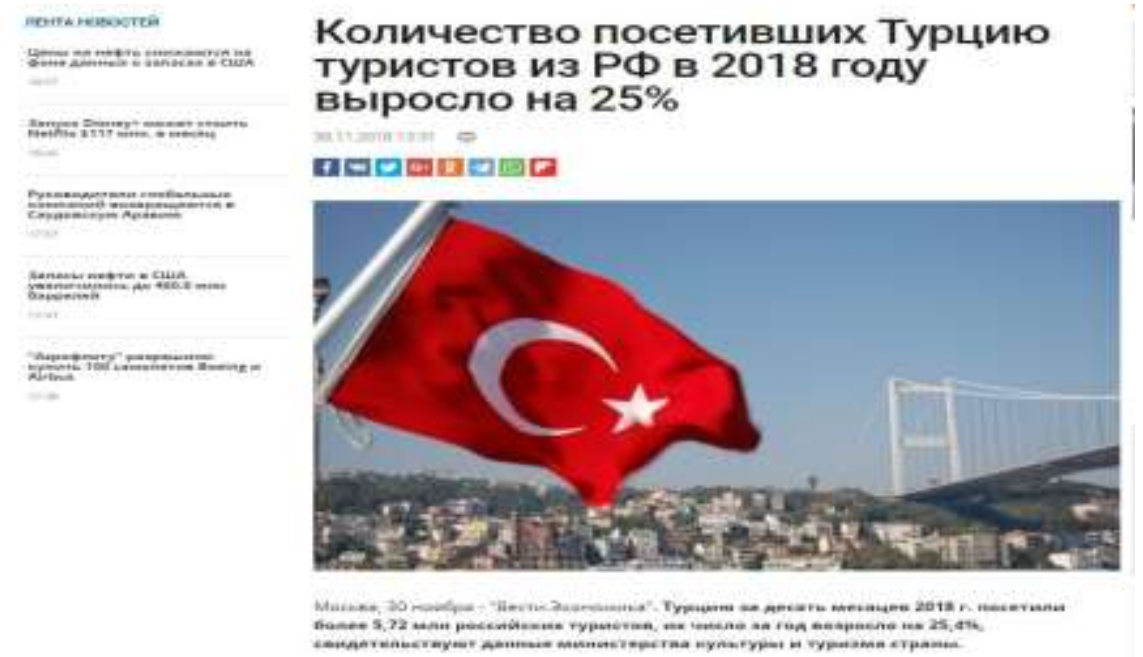

https://www.vestifinance.ru/articles/111051

\section{CONCLUSION}

Deepening the relationship between Turkey and Russia in the XXI century. served as a good material for journalists in both countries. Of the numerous meetings of leaders, negotiations and trade conflicts that occurred between the two countries, as well as negotiations on the construction of the South Stream gas pipeline in Turkey's zone of exclusive economic interests. The Russian and Turkish press extremely ambiguously interpreted these events, and the assessment depended not only on the nationality of the media, but also on the political affiliation of the news sites and this is especially characteristic of the Turkish side. However, in the course of the development of the situation, the journalists worked out an adequate point of view, contributing to the creation of a positive image of Russian-Turkish relations (Öztürk, 2017: 147).

The energy sector was mainly covered in the context of Turkey's gas supplies. Implementation of the agreements of Turkey and Russia in the field of nuclear energy. One of the contexts of the mention 
in Social Sciences

of Turkey in the Russian mass media is the tourism industry. Another topic that attracts the attention of the Russian media is the safety of tourists in Turkish resorts.

Aknowlegement: This paper is supported by Kahramanmaras Sutcu Imam University

\section{REFERENCES}

1. MIRNaS (2015). “Обзор Представленности Турции В Российских Сми И России В Турецких Сми”.

2. A. Öztürk, “СМИ России и Турции в период многопланового двустороннего партнерства (2000-2015 гг.)", Ph.D. dissertation, Санкт-Петербургский Государственный Университет, 2017.
Internet resources

1. http://www.hurriyet.com.tr/dunya/idlibdesilahlardan-arindirilmis-bolgeden-cikissinyalleri-40969246

2. www.dw.com/ru/какую-цельпреследует-турция-в-сирии/а-43080992

3. https://tr.sputniknews.com/columnists/201 $\underline{807061034177253 \text {-rusya-turkiye-sattigi- }}$ gazin-fiyatini-artiracak-mi/

4. https://iz.ru/748313/2018-05-26/rossiiapredostavila-turtcii-skidku-na-gaz-na-1$\underline{\text { mlrd }}$

5. www.ntv.com.tr/dunya/rusyada-federalguvenlik-servisi-binasina-terorsaldirisi,tqQ orNoDUygp7S9E9bLSQ

6. https://riafan.ru/1037974-terror-pokurdski-vzryvy-i-krov-pod-nebom-turcii

7. www.haberturk.com/rus-turistlerin-2018de-gozdesi-turkiye-oldu-2273581-ekonomi

8. https://www.vestifinance.ru/articles/11105 1 